\title{
Every breath you take. Every freight you make: environmental pollution index for road transportation
}

\author{
Luciana Oranges Cezarino 1,2, Lorena Costa Baesse², Adhemar Ronquim Filho ${ }^{3,4}$, \\ Marlos Rocha de Freitas ${ }^{2}$ \\ ${ }^{1}$ Ca' Foscari University of Venice, Department of Management, BLISS Digital Impact, Venice, Italy. \\ ${ }^{2}$ Federal University of Uberlândia - UFU, School of Business and Management, Uberlândia, MG, Brazil. \\ ${ }^{3}$ University of São Paulo - USP, School of Economics, Accounting and Management of Ribeirão Preto - FEA-RP, Ribeirão \\ Preto, SP, Brazil. \\ ${ }^{4}$ University of Araraquara - UNIARA, Department of Legal Sciences, Araraquara, SP, Brazil.
}

How to cite: Cezarino, L.O., Baesse, L.C., Ronquim Filho, A. et al. (2022), “Every breath you take. Every freight you make: Environmental pollution index for road transportation", Brazilian Journal of Operations \& Production Management, Vol. 19, No. 1, e20221049. https://doi.org/10.14488/BJOPM.2021.038

\begin{abstract}
Goal: This study analyzes the impacts of the transportation sector on air pollution within the scope of one major Brazilian metropolitan region.

Design / Methodology / Approach: A literature review was conducted on the subject's constructs, with subsequent reasoning grounded on the fleet's characteristics and data obtained from in-depth interviews from a government transportation agency.

Results: The results show Brazil's contextual evidence that risk management for the haulage sector should consider air pollution's negative impacts. With air quality standards as an essential reference, it is possible to observe that the city of Uberlândia does not effectively manage air quality.

Limitations of investigation: One limitation of this research is related to the representativeness of the sample. The research also recommends future studies to use government policies for the improvement of the framework.

Practical implications: The local and contextual addressing of air pollution and transport correlation in one focal point for cargo transportation at a national level pontentially contributes to environmental public policies.

Originality / Value: Originality value resides in considering emissions from cargo vehicles as a significant factor in this process of air pollution in a specific context of a metropolitan area of an emerging economy that has its transportation modal grounded on trucking freight.
\end{abstract}

Keywords: Environment; Air Pollution; Pollutant Emissions; Road transportation; Diesel Oil; Haulage.

\section{INTRODUCTION}

The evolution of road transport, starting in the 1950s, occurred at an extremely rapid pace in Brazil. Between 1945 and 1952, the number of trucks and buses in circulation jumped from 103,000 to 265,000 , a growth of more than $157 \%$ in just seven years (Institute of Interamerican Affairs, 1954). In the 1960s, freight movement shift from railroads and cabotage (coastal navigation) to highways. Since then, the roads were responsible for

Financial support: Minas Gerais Research Funding Foundation (Fapemig).

Conflict of interest: The authors have no conflict of interest to declare.

Corresponding author: luciana.cezarino@unive.it

Received: 22 July 2020.

Approved: 8 April 2021

Editor: Julio Vieira Neto. 
about $73 \%$ of all freight movement in Brazil (Barat, 1978). A modern highway system would be the fastest way to achieve its tremendous national objective of social, economic, and political integration (Amann et al., 2016; Southworth et al., 2011; Galvão, 1996).

From the business view, transportation is part of the logistics and distribution system. The freight value is responsible for a large share of the product's total cost, affecting its competitiveness (Coleti and Oliveira, 2019). The aim is to maximize the profit generated by the services performed (Alvarez-Cruz et al., 2019). It imposes the need to improve the choice of transport modal by companies, which depends, in turn, on the existence of viable alternatives to be used (Catela and Seabra, 2017). Road freight transport is an important activity for a country's economy. This is no different in Brazil (Martins et al., 2012): without it, the other economic sectors' production would not be advantageous since the goods produced could not reach their final consumers. This time, economic agents adobly need the transportation sector for the proper development of their business.

On the other hand, the economic growth fostered by fossil fuel transportation has its side effects (Hao et al., 2018): the anthropogenic emissions of gases and particulates tend to intensify progressively, leading to an increase in their concentration in the atmosphere (Stern and Van Dijk, 2017). Some of these gases and particles have proven effects on human health and the Environment, so they are considered "atmospheric pollutants." Among these, carbon monoxide (CO), hydrocarbons $(\mathrm{HC})$, particulate matter (PM), and nitrogen oxides (NO2) are highlighted (Santana et al., 2012). Air quality degradation is an utmost threat to human health, especially in urban centers, and has been associated with worsening of respiratory (Kim et al., 2018), cardiovascular (Yang et al., 2019), and neurological diseases (Calderón-Garcidueñas et al., 2016), especially in children and the elderly population. Studies also indicate the correlation between exposure to some pollutants and the occurrence of different types of cancer (World Health Organization, 2000; Gouveia et al., 2006; Brunekreef et al., 2012).

The impacts of air pollution on ecosystems also deserve attention. The deposition of air pollutants in plants can lead to a reduction in their photosynthesis capacity, leading to, for example, a problem in agricultural productivity. Acidification of rainwater and dust contaminating water resources, aquatic biomes, and the soil is also a consequence of the anthropic introduction of pollutants into the atmosphere (Santana et al., 2012). People's health is linked to the degree of air pollution, which is influenced by means of transport.

At the international level, this was the trigger for one of the most legitimacy damaging scandals in recent years: the V.W. Emissions scandal (Cavico and Mujtaba, 2016).

Thus, the present study aims to contribute to this discussion and analyze air pollution characteristics under the lens of the freight transportation industry in the Brazilian city of Uberlandia, quantifying the primary atmospheric pollutants to advance in this region's emissions studies and public policy implementation.

\section{LITERATURE OVERVIEW}

\section{Air pollution and road transportation}

$\mathrm{CO} 2$ is the primary GHG both in the world and in Brazil. The most significant share among the six gases responsible for climate change and tackling carbon dioxide emissions is considered the foremost sustainable development goal (Rüstemoğlu and Andrés, 2016). In a longitudinal study from 1992 to 2011, the economic activity responsible for most of the Brazilian CO2 emissions was transportation (42\% - 44\%) (Rüstemoğlu and Andrés, 2016) while many automobiles run on biodiesel local alternatives like alcohol blend fuels (Vieira et al., 2018), the Brazilian buses and trucks mostly run on Diesel Oil. In Brazil, road transportation is the main modal of a deeply asymmetric matrix for product logistics: the truck fleet is old and energy inefficient (Galbieri et al., 2017), yet trucking freight transport is responsible for $60 \%$ of diesel-oil consumption (Empresa de Pesquisa Energética, 2015). In the last century, this 
centralization has not undergone any significant advance regarding environmental issues, consequently impacting the Brazilian Environment and population well-being.

Air pollution impacts are transboundary (Zhang et al., 2017), and its effects are felt by the population and impact social and economic activities, biota, sanitary conditions (Brasil, 1981). A large fleet contributes widely to numbers of lethality both in Brazil and in other countries. WHO captured in 2014 close to four million deaths from air pollution, especially in developing countries (Chiquetto, 2019). It is a latent public health problem, which in addition to the number of deaths, causes respiratory, cardiovascular diseases, cancer, and other complications related to pregnancy and children (Cepeda et al., 2017). The fact that Brazil bet on road freight transport at the expense of more significant investment in air, waterway, and rail modals, as it is showed in Table 1, compared to other countries contributes to the number reproduced above. Due to its complexity, road transport consumes oil in considerable amounts, which increases air pollution.

Table 1 - Brazilian cargo transport matrix

\begin{tabular}{ccc}
\hline Type & $\begin{array}{c}\text { TKU (tons per useful } \\
\text { kilometer) }\end{array}$ & PERCENTAGE \\
\hline Road & 485.625 & $61,1 \%$ \\
Rail & 164.809 & $20,7 \%$ \\
\hline AQUAVIARY & 108.000 & $13,6 \%$ \\
\hline PIPELINE & 33.300 & $4,2 \%$ \\
\hline Air & 3.169 & $0,4 \%$ \\
\hline TOTAL & 794,903 (million) & $100 \%$ \\
\hline
\end{tabular}

Source: Colavite and Konishi (2015).

This cargo flow through the road modal represents Brazil's economic scenario: integrating large, medium, and small companies, the transport industry can generate work for larger shares of the active population. With the increase in road transport of cargo, the supply chain remains dependent, being a relevant cause of air pollution (table 2), which creates a multidimensional challenge for the reduction of pollutants, aiming at new energy sources (i.e., the gradual replacement of diesel) without hindering the country's significant economic industry.

Table 2 - Carbon Dioxide Emissions distribution

\begin{tabular}{cc}
\hline Type & Emission Of Carbon Dioxide Per Modal In \% \\
\hline Road & $86 \%$ \\
\hline Rail & $7 \%$ \\
\hline Cabotage (Coastal Navigation) & $5 \%$ \\
\hline Waterway & $2 \%$ \\
\hline
\end{tabular}

Source: EPL (Plano Nacional de Logística, 2016)

Regarding the regulation of the dangerous cargo to the Environment, there was the publication of Resolution No. 5,232/2016, the Brazilian National Agency of Land Transportation (ANTT) which, to discourage less caution by operators, imposed obligations, and, as non-compliance, and can generate confiscation of products and fines, among other sanctions. The standard does not care about penalties and the approval of values, but to stimulate environmental responsibility and minimize pollution and possible disasters on the environment.

One decarbonization pathway among a plethora of alternatives is the electrification of road transport (Nicolaides et al., 2017), reducing dependence on oil and the proliferation of air pollution (Weiss et al., 2015). Many success cases exist in countries like Canada (Bahn et al., 2013) and United States (Talebian et al., 2018). This approach tends to make the industry more renewable-resource centered and efficient energy (Frey, 2018). 
Air pollution from modal transport is transfigured as an externality of this activity, bringing costs to direct non-users (Castro, 2013). The Air Pollution Control Program for Motor Vehicles (PROCONVE), established in 1986, promotes national technological development, both in automotive engineering, as well as in methods and equipment for tests and measurements of pollutant emissions and the improvement of the technical characteristics of liquid fuels, made available to the national fleet of motor vehicles (Brasil, 1986). Until the program's creation, there were no guidelines for the emission of road transport pollutant gases; the program established stricter parameters for control of emissions and attributed supervision responsibilities to environmental authorities.

As possible improvements in the framework, evaluate, and quantify the potential of $\mathrm{CO} 2$ mitigation in road transport of cargo stemming from the adoption of measures and technologies to promote the reduction of fuel consumption (Bartholomeu et al., 2016). Other potential measuring efforts to reduce consumption can be implemented from investments by the truck manufacturer industry to develop technologies aimed at increasing vehicle efficiency (Bartholomeu et al., 2016).

\section{Focal interstate freight transportation: the context of the Brazilian "Triângulo Mineiro."}

The spatial distribution of transport logistics in the Brazilian territory has a predominance of highways, mainly concentrated in the Center-South of the country (Instituto Brasileiro de Geografia e Estatistica, 2014). According to the National Transportation Confederation (CNT), $61.1 \%$ of all freight transported in Brazil uses the road system, $21.0 \%$ railroads, $14 \%$ by waterways, rivers, and seaport terminals, and only $0.4 \%$ by air. According to the government of Minas Gerais state, the Triângulo Mineiro region is one of the most productive and promising areas of the country due to agribusiness economic success. The Triângulo Mineiro represents $7 \%$ of the state's total exports, which alone accounts for $13.8 \%$ of Brazil's external sales, causing an intense flow of freight transportation in the region. The main products exported in the region are sugar, coffee, corn, soy, and its derivatives. Also significant is the production and export of poultry, beef, and pork (Minas Gerais, 2018).

The National Land Transport Agency (ANTT), the National Department of Transport Infrastructure (DNIT), and the Minas Gerais and Goiás states highway concessionary company (MGO) entered into an agreement transferring to the concessionaire the section of highway BR-050 in the state of Minas Gerais (2018). From then on, MGO has had monthly traffic control in this region. Section P4 (Araguari 2) and section P5 (Uberaba) are the sections that have access to the city of Uberlandia, the municipality related to this research. In this way, it is possible to calculate the average quantity of freight vehicles that pass through the city of Uberlandia per month using BR-050. According to the traffic control of MGO, Figure 1 the average monthly number of trucks passing through Araguari toll plaza (section P4) is 101,714 and through the Uberaba toll plaza (section P5) 124,904 trucks.

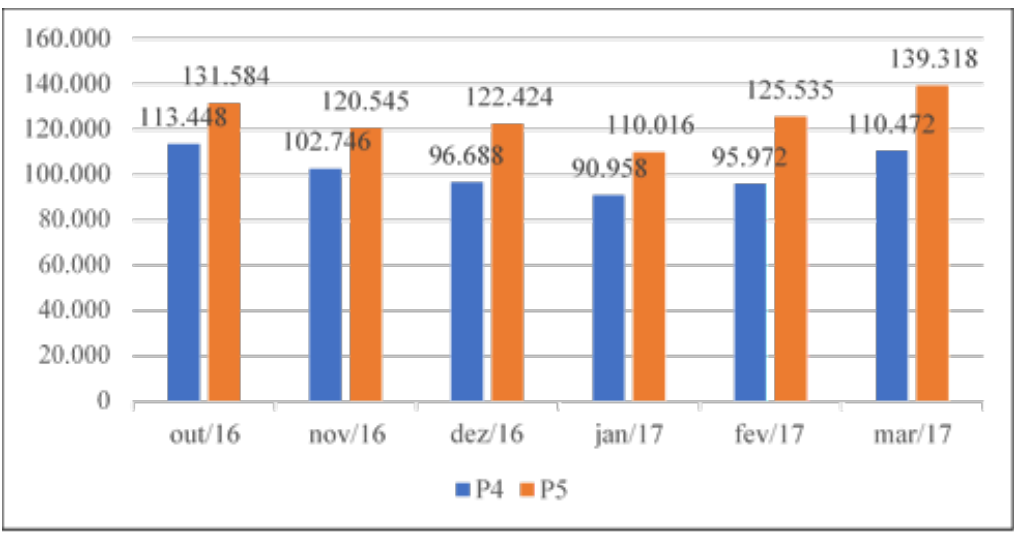

Figure 1 - Number of trucks per month - Traffic Control - MGO (Sections P4 and P5)

Source: Adapted from MGO (Minas Gerais, 2018) 


\section{Fleet description in Brazil}

According to National Land Transport Agency (ANTT), Brazil has 1,682,398 freight vehicles, including cooperatives, companies, and self-employed, representing a total of 494,815 agents and organizations involved in cargo transportation presented in Table 3.

Table 3 - Freight transport vehicles in Brazil- ANTT

\begin{tabular}{ccccc}
\hline & Self- employed & Companies & Cooperatives & Total \\
\hline Registrations Issued & 380,825 & 113,715 & 275 & 494,815 \\
\hline Vehicles & 564,404 & $1,095,122$ & 22,872 & $1,682,398$ \\
\hline
\end{tabular}

Source: ANTT (Agência Nacional de Transportes Terrestres, 2017)

A large number of self-employed is due to the custom that companies have to aggregate their fleets with vehicles owned by third parties (self-employed truck drivers). All that is needed is to comply with some contractual requirements and formalities, and the self- employed truck drivers start to transport the products under the companies' responsibility, thus integrating the business activity (Brasil, 2017).

According to the Triângulo Mineiro Transport Union (SETTRIM), in the Minas Gerais Triangle Region, a total of 3,145 transporters, including self-employed, companies and cooperatives, are cataloged. In the city of Uberlandia, 1,738 transporters are located, which corresponds to $55 \%$ of the total (Sindicato das Empresas de Transporte de Cargas do Triângulo Mineiro, 2017), as seen in Figure 2.

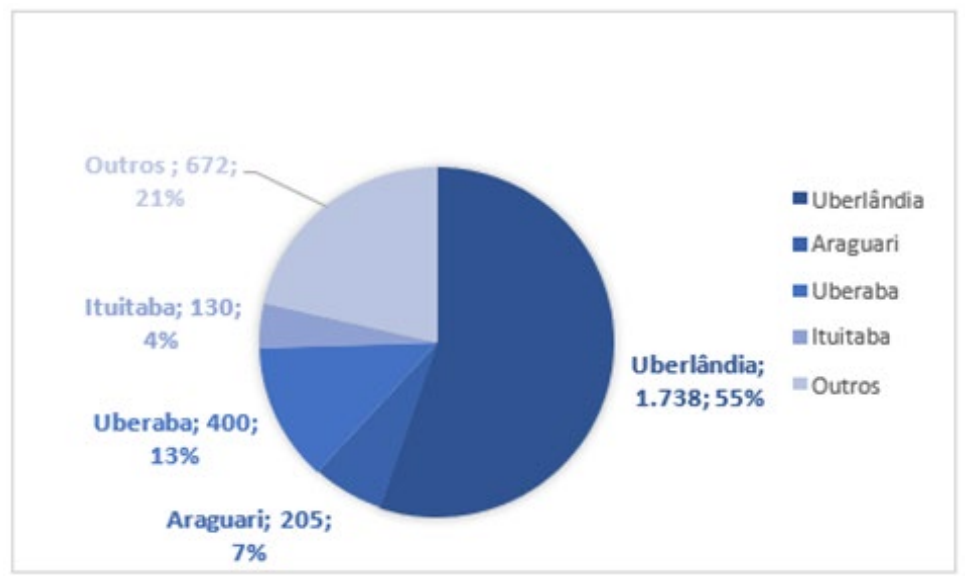

Figure 2 - Quantity of Transporters by Municipality

Source: Adapted from SETTRIM (Sindicato das Empresas de Transporte de Cargas do Triângulo Mineiro, 2017)

According to the data collected in Uberlandia, of the 1,738 transporters, only 80 companies and one cooperative carry out monitoring of emission of atmospheric pollutants, which is carried out together with the Despoluir program and SETTRIM, using as emission parameter limits the maximum levels found in CONAMA Resolution No. 418, of $25^{\text {th }}$ November 2009 (Sindicato das Empresas de Transporte de Cargas do Triângulo Mineiro, 2017).

This research considered the transporters of Uberlandia that have been monitoring atmospheric pollutants' emission as the target audience. A total of 81 transporters (80 companies and one cooperative) were identified, comprehending 2,503 vehicles. According to data collected for this research, in Uberlandia, only $31 \%$ of the cars have engines with new technologies capable of using S10 Diesel, $69 \%$ are older than necessary for S10 and use S500 diesel.

S10 diesel is only used for new diesel engines manufactured from 2012, which have new emission control technologies. S10 diesel enables the reduction of emissions of 
particulate matter up to $80 \%$ and of nitrogen oxides up to $98 \%$ (Petrobras, 2017). It is currently estimated that Brazil has about 230 thousand trucks with more than 30 years of use. These vehicles have outdated technology and pollute more than new trucks (Brasil, 2017). One of the reasons for this is the use of S500 diesel that causes these vehicles to have a higher atmospheric emissions rate.

\section{Diesel oil in Brazil}

According to the definition of the National Agency of Petroleum, Natural Gas and Biofuels (Agência Nacional do Petróleo, Gás Natural e Biocombustíveis, 2017), diesel is described as a petroleum-derived liquid fuel composed of hydrocarbons with chains of 8 to 16 carbons, in addition to nitrogen, sulfur, and a lesser extent, oxygen. Diesel oil, in its various denominations, is the primary fuel commercialized in the Brazilian market and is mostly used in diesel-based engines of internal combustion and compression ignition (Agência Nacional do Petróleo, Gás Natural e Biocombustíveis, 2017).

Freight transportation in Brazil is mainly supported by vehicles powered by diesel engines by road. Several types of diesel and respective applications are found in the market; in the national territory, ANP establishes S10 and S500 diesel oil for road use, S1800 diesel oil for non-road use, and marine diesel DMA/DMB for use by marine vessels.

The pollutants emitted by diesel's combustion promote ecological problems recognized worldwide, such as the destruction of the ozone layer, the increase of global warming, and acid rain (Knothe et al., 2005). Diesel engines emit particulate matter, black smoke and carry various carcinogenic compounds with a high impact on human health and ecosystems (Correa and Arbilla, 2006).

The compounds of diesel engine emissions are classified into two forms: those that do not cause damage to health, i.e., $\mathrm{O} 2, \mathrm{CO} 2, \mathrm{H} 2 \mathrm{O}$, and $\mathrm{N} 2$; and those that provoke health problems, being subdivided into compounds that have emission regulations, which are: carbon monoxide (C.O.), hydrocarbons (H.C.), nitrogen oxides (NOX), sulfur oxides (SOX), and particulate matter (PM); and those that are not yet under regulation, being aldehydes, ammonia, benzene, cyanides, toluene and polynuclear aromatic hydrocarbons (PAH) (Neeft et al., 1996).

Diesel exhaust is complex, composed of three phases: solids, liquids, and gases (Degobert, 1995). Operation under diesel engine oxidizing conditions at lower temperatures can be compared with gasoline engines, with lower production of $\mathrm{CO} 2$, NOX, CO, and hydrocarbons (H.C.). However, this process also results in high emission levels of particulate matter (PM) and compounds responsible for the diesel emission's odor characteristic, the latter emission being much worse during low temperature operating conditions (Neeft et al., 1996).

Hydrocarbons from diesel emissions are generally heavier than those from gasoline emissions; also, polycyclic aromatic hydrocarbons (PAH) and alkyl derivatives thereof may be present in the diesel, thus resisting the combustion process, volatilizing and escaping into the atmosphere by exhaustion (Scheepers and Bos, 1992).

\section{Diesel into the atmosphere: a public concern externality}

\section{Particulate matter}

In 2011, Petrobras signed a cooperation agreement with the University of São Paulo (Universidade de São Paulo - USP) and the Catholic University of Rio de Janeiro (Universidade Católica do Rio de Janeiro - PUC-RJ) to study the influence of the primary emitting sources on the formation of particulate matter (PM), especially PM2.5 
(particulate matter with a diameter of less than $2.5 \mu \mathrm{m}$ ). This initiative was called the "Sources Project" (Projeto Fontes).

PM emission level in light diesel vehicles is much higher than that of Otto cycle vehicles and motorcycles. For vehicles of previous phases ( $L 3$ and $L 4$ of PROCONVE), there was no evidence of a decrease in PM emission due to the reduction of the sulfur content of the fuel, while in the more recent vehicles (L6), this was noticeable as showed by Figure 3.

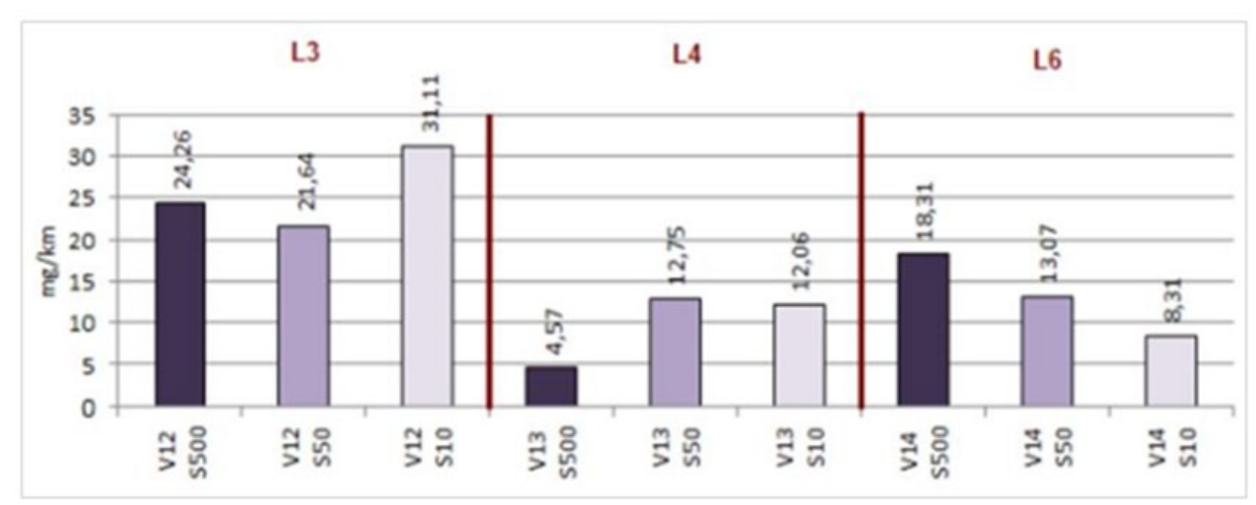

Figure 3 - PM2.5 emission in heavy diesel cycle vehicles. Note: Emission factors for heavy diesel cycle vehicles with S500, S50, and S10.

Source: Adapted from Projeto Fontes.

In heavy diesel engines, this influence is perceived when the diesel oil's sulfur content was reduced to below 500 ppm, but it was not evident between the contents of 50 and $10 \mathrm{ppm}$. The numbers are presented in Figure 4.

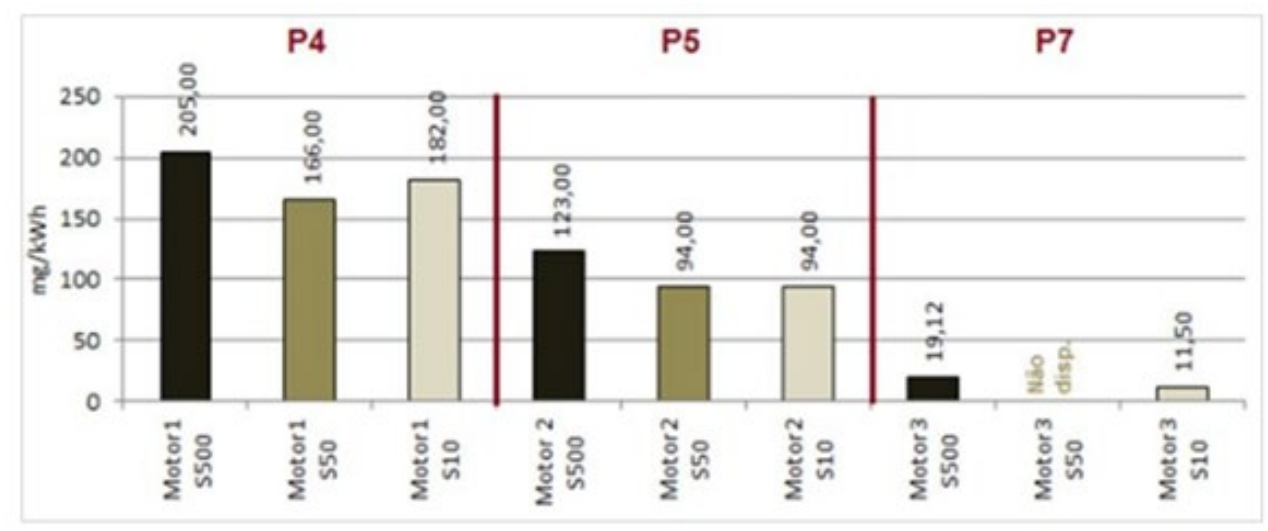

Figure 4 - PM2.5 emission in heavy diesel cycle vehicles. Note: Emission factors for heavy diesel cycle vehicles with S500, S50, and S10.

Source: Adapted from Projeto Fontes.

\section{PROCONVE}

Negative societal and environmental externalities caused by economic activities are a matter of concern to private business but mostly to public agency, since the stakeholder is affected on a broader scope. On 06th May 1986, CONAMA Resolution No. 18 created the Air Pollution Control Program for Automotive Vehicles (PROCONVE) (Brasil, 1986), which defined the first emission limits for light vehicles, and contributes to meeting the Air Quality Standards instituted by the National Air Quality Control Program. Table 4 represents the implementation strategy for heavy vehicles. 
Table 4 - PROCONVE implementation strategy for heavy vehicles

\begin{tabular}{ccl}
\hline Phase & Implantation & Feature / Innovation \\
\hline P1 and P2 & $1990-1993$ & $\begin{array}{l}\text { In 1990, engines with lower emission levels were being produced than } \\
\text { those that would be required in 1993 (the year in which emission } \\
\text { control for vehicles of this type began with the introduction of phases } \\
\text { P1 and P2. In that period, the limits for gas emissions (phase P1) and } \\
\text { particulate matter (phase P2) were not legally required. } \\
\text { The development of new engine models aimed at reducing fuel } \\
\text { consumption, increasing power, and reducing emissions of nitrogen } \\
\text { oxides (NOx) through the adoption of intercooler and turbo engines. } \\
\text { There was a drastic reduction in CO (43\%) and H.C. (50\%) emissions in } \\
\text { this phase. }\end{array}$ \\
\hline P3 & $1994-1997$ & $\begin{array}{l}\text { It further reduced the limits created by Phase P3. } \\
\text { It aimed to reduce emissions of particulate matter (PM), NOx, and H.C. }\end{array}$ \\
\hline P5 & 2003-2008 & $\begin{array}{l}\text { In January 2009, the start of phase P6 should have occurred, } \\
\text { according to CONAMA resolution 315/2002, whose main objective, as } \\
\text { in phase 5, was to reduce emissions of particulate matter (PM), NOx, } \\
\text { and H.C. }\end{array}$ \\
\hline P6 & $2009-2011$ &
\end{tabular}

Source: PROCONVE (Brasil, 2017)

\section{Opacity}

The Despoluir project, a national scheme to control atmospheric emissions by automotive vehicles, is managed in Uberlandia by Triângulo Mineiro Transport Union (SETTRIM). In this project, the diesel cycle vehicles are subjected only to the opacity test that evaluates the amount of light that crosses a specific matter, classifying the opacity of the emitted smoke (Sindicato das Empresas de Transporte de Cargas do Triângulo Mineiro, 2017). The test is performed with an opacimeter device, which emits a beam of light, thus measuring the light permeability in the exhaust smoke. The vehicle is subjected to at least four accelerations to capture the smoke; this smoke is analyzed by the opacimeter, which compares the result with the values referenced by the current federal standard of CONAMA. Data obtained by the opacity test shows the average number of vehicles inspected monthly is approximately 293 , out of the total of 2,503 , as illustrated by Figure 5 .

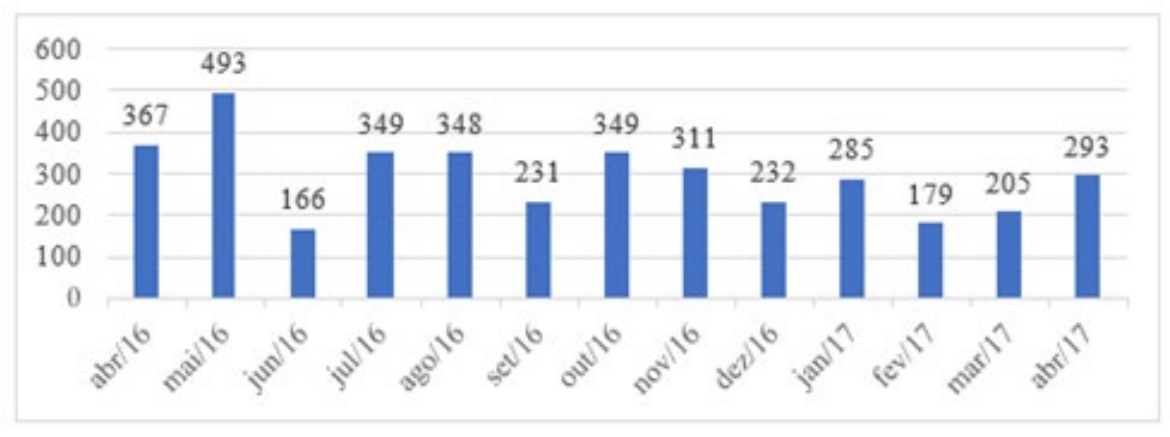

Figure 5 - Vehicles Inspected per Month

Source: Adapted from SETTRIM (Sindicato das Empresas de Transporte de Cargas do Triângulo Mineiro, 2017)

Most of the vehicles were approved in the test, with an annual approval average of approximately $65 \%$, as represented by Figure 6 . 


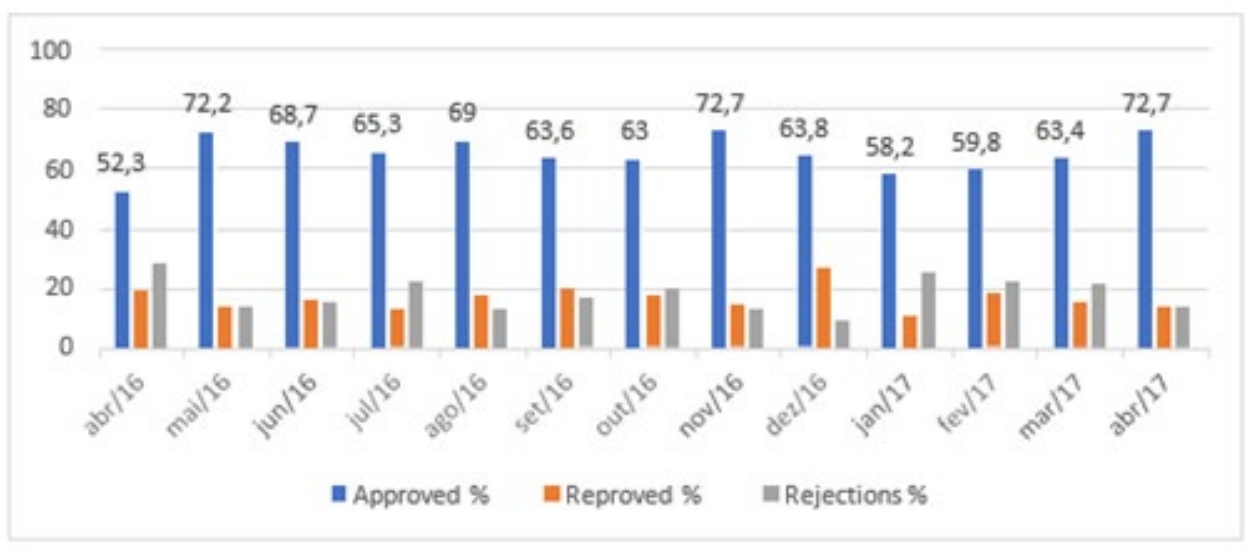

Figure 6 - Result of Opacity Test

Source: Adapted from SETTRIM (Sindicato das Empresas de Transporte de Cargas do Triângulo Mineiro, 2017)

\section{METHOD}

A bibliographical review was carried to foster the study's reasoning and support the main objective of developing an atmospheric pollution index using data generated by the distribution of road transport in the city of Uberlandia. The purpose of the review was the need for information that made it possible to verify the variables necessary to calculate the pollution index and perform an analysis of freight transportation in the Triângulo Mineiro region. For this, different databases were explored, both academic like the Coordination for the Improvement of Higher Education Personnel (CAPES) journal portal and the digital thesis portal from the University of Sao Paulo and also from grey literature like the National Agency of Land Transportation (ANTT) and the National Transportation Confederation (CNT) database. After interpreting the selected works, it was possible to find information on the number of transporters in Brazil and the number of freight vehicles and their average age.

Interviews were conducted in a face-to-face meeting with employees of the SETTRIM; in-depth interviews are used to obtain as much detailed information as possible about a specific topic (Minayo, 1993). The conversation guidelines addressed the fleet's characterization of the transport and logistics companies of the municipality of Uberlandia.

\section{The calculation for emissions of Hydrocarbons (H.C.), Carbon Monoxide (C.O.), and Nitrogen Oxide (NOx)}

The U.S. Environmental Protection Agency (EPA) methodology for calculating atmospheric emissions was used as a reference. However, effective use needed to make contextual adjustments for the Triângulo Mineiro region and adjust the year of manufacture of the vehicles from 2017 since the table's source was from 2009. In this way, it provided data for vehicles from 2009. The change of the year of manufacture of the vehicles in the table does not interfere in the final result since what matters is the vehicle's age, thus keeping the emission and deterioration values consistent. To obtain emission rates for hydrocarbons (H.C.), carbon monoxide (C.O.) and nitrogen oxides (NOx), the actual values offered by the EPA of emission factors and deterioration factors for the years 2017 to 2005; and for the years 2004 to 1994 an average of the values of the factors released by the EPA, shown in Table 5, were performed. 
Table 5 - Emission (E.F.) and deterioration (D.F.) factors for hydrocarbons, carbon monoxide, and nitrogen oxides, in grams per mile, for heavy diesel vehicles at high altitudes.

\begin{tabular}{ccccccc}
\hline \multirow{2}{*}{$\begin{array}{c}\text { Year of } \\
\text { manufacture }\end{array}$} & \multicolumn{2}{c}{ Hydrocarbons } & \multicolumn{2}{c}{ Carbon monoxide } & \multicolumn{2}{c}{ Nitrogen oxides } \\
\cline { 2 - 7 } & F.E. & F.D. & F.E. & F.D. & F.E. & F.D. \\
\hline 2017 to 2005 & 4.82 & 0 & 16.665 & 0.08 & 6.49 & 0 \\
\hline 2004 to 1994 & 5.026 & 0 & 17.363 & 0.084 & 13.902 & 0 \\
\hline
\end{tabular}

Source: EPA (United States Environmental Protection Agency, 2017)

The EPA provides data for two types of the region: low altitude and high altitude. The state of Minas Gerais is considered the highest altitude in Brazil due to the characteristics of its relief, thus justifying the use of the factors for high altitude regions. The average annual value of 124,800 kilometers was performed by making the summation of the monthly average, provided by the CNT survey, of $10,400 \mathrm{~km} / \mathrm{month}$. Lastly, data on the Uberlandia state fleet provided by SETTRIM were required. Only 2,503 freight vehicles were considered, corresponding to the vehicles that carry out emission monitoring of atmospheric pollutants in Uberlandia. Data from the fleet of diesel vehicles were organized by age group as stipulated by the EPA and are presented in Table 1. The calculation of the emission rate of the indicated pollutants is equivalent to the multiplication of the deterioration factor by the average number of kilometers, divided by 10,000 miles, added to the emission factor of vehicles, and it is possible to estimate by Equation:

Total issue $=\sum N i\left(F E i+F D i * \frac{\text { Milhasi }}{10000}\right)$

It is important to note that the data in Table 1, provided by the EPA, are in grams per mile, so conversions are required to show the results grams $/ \mathrm{km}$, based on the onemile ratio of 1.609344 kilometers. Based on the emission and deterioration factors presented in Table 1 and the distribution of the fleet of heavy diesel-powered vehicles per year of manufacture, the total emission of each pollutant in grams can be estimated by equation:

Total emission $=\sum N i\left(\frac{F E i}{1.609344}+\frac{F D i}{1.609344} * \frac{124800 \mathrm{~km}}{10000 * 1.609344 \mathrm{~km}}\right)$

Where Ni represents the total of vehicles with a year of manufacture "i"; FEi and FDi are the emission and deterioration factors for each pollutant, in grams per mile, for each vehicle with a year of manufacture belonging to the " $i$ " range; and "Milhasi" corresponds to the accumulated total of miles traveled by vehicles with a year of manufacture belonging to the "i" range.

\section{The calculation for particulate matter emissions with a diameter of less than $\mathbf{2 . 5}$ $\mu \mathrm{m}$ (PM2.5).}

For the calculation of the emission estimate of the particulate matter, the "Projeto Fontes" was used as a reference, which is a study carried out through the cooperation agreement between Petrobras with USP and PUC-RJ to analyze the influence of the primary emitting sources on the formation of particulate matter (PM), especially PM2.5 (particulate matter with a diameter of less than $2.5 \mu \mathrm{m}$ ).

Through the data provided by this study, it was possible to apply its results to the fleet data of the vehicles studied herein, thus determining the average particulate matter produced by the vehicles monitored in Uberlandia. 


\section{RESULTS}

The results will be presented in four topics to facilitate the reader's understanding: 1) Hydrocarbons, 2) Carbon Monoxide, 3) Nitrogen Oxide, and 4) Particulate Matter.

\section{Hydrocarbons}

Total emission $=\sum N i\left(\frac{F E i}{1.609344}+\frac{F D i}{1.609344} * \frac{124800 \mathrm{~km}}{10000 * 1.609344 \mathrm{~km}}\right)$

Total emission $=\sum($ fleet emission aged 2017 to 2005 $)+($ fleet emission aged 2004 to 1994$)$

Emission fleet $(2017$ to 2005$)=1770\left(\frac{4.82}{1.609344}+\frac{0}{1.609344} * \frac{124800}{10000 * 1.609344}\right)$

Emission fleet $(2017$ to 2005$)=1770 * 2.9950$

Emission fleet $(2017$ to 2005$)=5301.16 \mathrm{~g} /$ year

Emission fleet $(2004$ to 1994$)=733\left(\frac{5.026}{1.609344}+\frac{0}{1.609344} * \frac{124800}{10000 * 1.609344}\right)$

Emission fleet $(2004$ to 1994$)=733 * 3.1230$

Emission fleet $(2004$ to 1994$)=2289.18 \mathrm{~g} /$ year

Total Emission $=$ Emission $(2017$ to 2005) + Emission $(2004$ to 1994)

Total Emission $=5301.16+2289.18$

Total Emission $=7590.32 \mathrm{~g} /$ year $=7.6 \mathrm{~kg} /$ year

For the fleet of 2,503 heavy freight vehicles in Uberlândia, $7.6 \mathrm{~kg}$ of hydrocarbons is emitted every year.

\section{Carbon Monoxide}

Total emission $=\sum N i\left(\frac{F E i}{1.609344}+\frac{F D i}{1.609344} * \frac{124800 \mathrm{~km}}{10000 * 1.609344 \mathrm{~km}}\right)$

Total emission $=\sum($ fleet emission aged 2017 to 2005 $)+($ fleet emission aged 2004 to 1994$)$

Emission fleet $(2017$ to 2005$)=1770\left(\frac{16.665}{1.609344}+\frac{0.08}{1.609344} * \frac{124800}{10000 * 1.609344}\right)$ 
Emission fleet $(2017$ to 2005$)=19010.52 \mathrm{~g} /$ year

Emission fleet $(2004$ to 1994$)=733\left(\frac{17.363}{1.609344}+\frac{0.084}{1.609344} * \frac{124800}{10000 * 1.609344}\right)$

Emission fleet $(2004$ to 1994$)=8198.42 \mathrm{~g} /$ year

Total Emission $=$ Emission $(2017$ to 2005) + Emission $(2004$ to 1994)

Total Emission $=19010.52+8198.42$

Total Emission $=27208.94 \mathrm{~g} /$ year $=27.2 \mathrm{~kg} /$ year

For the fleet of 2,503 heavy freight vehicles in Uberlândia, $27.2 \mathrm{~kg}$ of carbon monoxide is emitted per year.

\section{Nitrogen Oxide}

Total emission $=\sum N i\left(\frac{F E i}{1.609344}+\frac{F D i}{1.609344} * \frac{124800 \mathrm{~km}}{10000 * 1.609344 \mathrm{~km}}\right)$

Total emission $=\sum($ fleet emission aged 2017 to 2005 $)+($ fleet emission aged 2004 to 1994$)$

Emission fleet $(2017$ to 2005$)=1770\left(\frac{6.49}{1.609344}+\frac{0}{1.609344} * \frac{124800}{10000 * 1.609344}\right)$

Emission fleet $(2017$ to 2005$)=7137,87 \mathrm{~g} /$ year

Emission fleet $(2004$ to 1994$)=733\left(\frac{13.902}{1.609344}+\frac{0}{1.609344} * \frac{124800}{10000 * 1.609344}\right)$

Emission fleet $(2004$ to 1994$)=6677.4 \mathrm{~g} /$ year

Total Emission $=$ Emission $(2017$ to 2005) + Emission $(2004$ to 1994$)$

Total Emission $=7137.87+6677.4$

Total Emission $=13815.27 \mathrm{~g} /$ year $=13.82 \mathrm{~kg} /$ year

For the fleet of 2,503 heavy freight vehicles in Uberlândia, $13.82 \mathrm{~kg}$ of nitrogen oxide is emitted per year. 


\section{Particulate Matter}

Emission of PM2.5 in heavy diesel cycle engines

\section{- For $\mathbf{5 5 0 0}$ diesel}

$\bar{X}=\frac{P 4+P 5+P 7}{3} \bar{X}=\frac{\frac{205 m g}{k m}+\frac{123 m g}{k m}+\frac{19.12 m g}{k m}}{3} \quad \bar{X}=115.70 \mathrm{mg} / \mathrm{km}$

The average particulate matter (PM2.5) emitted by freight vehicles using S500 diesel is $115.70 \mathrm{mg} / \mathrm{km}$ per vehicle.

\section{- For S10 diesel}

$\bar{X}=\frac{P 4+P 5+P 7}{3} \bar{X}=\frac{\frac{182 \mathrm{mg}}{\mathrm{km}}+\frac{94 \mathrm{mg}}{\mathrm{km}}+\frac{11.50 \mathrm{mg}}{\mathrm{km}}}{3} \quad \bar{X}=95.83 \mathrm{mg} / \mathrm{km}$

The average particulate matter (PM2.5) emitted by freight vehicles using S10 diesel is $95.83 \mathrm{mg} / \mathrm{km}$ per vehicle.

Total emission average of PM2.5 in heavy diesel cycle engines for S500 and S10 diesel.

$\bar{X}=\frac{\bar{x} S 500+\bar{x} S 10}{2} \bar{X}=\frac{\frac{115.70 \mathrm{mg}}{\mathrm{km}}+\frac{95.83 \mathrm{mg}}{\mathrm{km}}}{2} \quad \bar{X}=105,76 \mathrm{mg} / \mathrm{km}$

Total emission generated by the vehicles of Uberlândia:

$T=a \bar{x} S 500+b \bar{x} S 10$

$T=1728 * 115.7+775 * 95.83 \quad T=199,929.6+74,268.25$

$T=274,197.85 \mathrm{mg} / \mathrm{km}=274.2 \mathrm{~g} / \mathrm{km}$

a: number of S500 fleet vehicles in Uberlândia;

b: number of $\mathrm{S} 10$ fleet vehicles in Uberlândia.

$\bar{x}$ S500: Average emission of vehicles using S500 diesel

$\bar{x}$ S10: Average emission of vehicles using S10 diesel

The emission of particulate matter (PM 2.5) generated by the sample's vehicles of this research, which corresponds to 2,503 freight vehicles, is $274.2 \mathrm{~g} / \mathrm{km}$.

PM indicator $=\frac{\text { Total emissions generated }}{\text { Pollution average }}=\frac{274,197.85}{264,717.28}=1.04$

\section{FINAL CONSIDERATIONS}

The development of solutions to mitigate air pollution calls for a comprehensive analysis: the problem is complex and can originate from several factors. However, considering the emissions of cargo vehicles as a significant factor in this process of pollution, the atmosphere can facilitate the identification of solutions to face this situation with greater efficiency. 
The S10 diesel, used only in engines manufactured since 2012, allows reducing the emission of particulate matter by up to $80 \%$ and nitrogen oxides by up to $98 \%$ (Petrobras, 2017). Itis currently estimated that Brazil has almost $14 \%$ of its cargo vehicle fleet with more than 30 years of use. About 230 thousand trucks use diesel S500 as fuel, which generates very high atmospheric emissions (Brasil, 2017).

Considering that $61.1 \%$ of cargo in Brazil is transported by the road system (Colavite and Konishi, 2015), that there are a total of 1,682,398 cargo vehicles in the country (Agência Nacional de Transportes Terrestres, 2017) and that only in the city of Uberlândia, which is an important logistics hub in Brazil, $69 \%$ of vehicles are older than necessary to use the S10 diesel (Agência Nacional de Transportes Terrestres, 2017), the present research indicates a significant opportunity to reduce air pollution by suggesting a more pronounced renewal of the vehicle fleet.

Thus, this study suggests intensively increasing the fleet of cargo vehicles' rates using S10 diesel technology. In this sense, a viable alternative would be to offer limited lines with incentives and low-interest rates to autonomous carriers and drivers to replace vehicles manufactured before 2012 with others that are technologically more modern and less polluting. As a side effect, there would also be a reduction in fleet maintenance costs for companies operating in goods' transportation.

The standards used by the EPA and the Sources Project were used as a reference to calculate the quantity of the primary air pollutants. During data collection in the city of Uberlândia, it was possible to notice a low adherence by city carriers to the environmental management system. Of the sample of 1,738 freight companies, only 81 carry out the monitoring of air quality in their fleet. In this work, the research sample considered only the companies that carry out this monitoring with supervision by SETTRIM. The results obtained were allowed to identify the following indices: Carbon Monoxide (CO) 27.2 kg/year, Nitrogen Oxide (NOx) 13, 82 kg/year, Hydrocarbons (H.C.) $7.6 \mathrm{~kg} / \mathrm{year}$, and Particulate Material $274.2 \mathrm{~g} / \mathrm{km}$.

One limitation of this research is related to the use of a small percentage sample. Besides, companies that were already concerned with the level of pollutant emissions and who spontaneously adhered to an air quality monitoring program were considered. As a result, the carriers contributing to this research may have a different fleet profile concerning the others, which may have generated indexes that do not necessarily represent the Uberlândia fleet.

Future research may consider replicating this study in other Brazilian regions to identify relevant differences in pollutant emission rates, generating more appropriate policies to address contextual realities. Another situation to assess would be to carry out comparative research with other countries to identify and disseminate the most efficient practices to mitigate pollutants' emission.

In this sense, having air quality standards as an essential reference, it is possible to observe that the city of Uberlândia does not have effective air quality management. This research also recommends using government policies to motivate a more significant number of cargo transportation companies to seek adherence to air quality monitoring in their fleets.

\section{REFERENCES}

Agência Nacional de Transportes Terrestres - ANTT (2017), Highways, available at: http://www.antt.gov.br/rodovias/index.html> (accessed 1 March 2017).

Agência Nacional do Petróleo, Gás Natural e Biocombustíveis - ANP (2017), Statistic data, available at: http://www.anp.gov.br/wwwanp/dados-estatisticos (accessed 1 April 2017).

Alvarez-Cruz, C. D., Munari, P. A. and Morabito, R. (2019), “Limites para o problema de alocação de veículos", Dyna rev.fac.nac.minas, Vol. 86, No. 208, pp. 329-35. http://dx.doi.org/10.15446/dyna.v86n208.68504. 
Amann, E., Baer, W., Trebat, T. et al. (2016), "Infrastructure and its role in Brazil's development process", The Quarterly Review of Economics and Finance, Vol. 62, pp. 66-73.

Bahn, O., Mathilde, M., Wuaab, K. et al. (2013), "Electrification of the Canadian road transportation sector: a 2050 outlook with TIMES-Canada", Energy Policy, Vol. 62, pp. 593-606.

Barat, J. (1978). The evolution of transport in Brazil, IPEA, Niterói.

Bartholomeu, D.B., Pera, T.G. and Caixeta-Filho, J.V. (2016), Logística sustentável: avaliação de estratégias de redução das emissões de $\mathrm{CO} 2$ no transporte rodoviário de cargas. Journal of Transport Literature, Vol. 10, No. 3, pp. 15-19. https://doi.org/10.1590/2238-1031.jtl.v10n3a3.

Brasil. Ministério dos Transportes, Portos e Aviação Civil. Agência Nacional de Transportes Terrestres ANTT. (2016). Resolução n. ${ }^{\circ}$ 5.232/2016, de 14 de dezembro de 2016. Aprova as Instruções Complementares ao Regulamento Terrestre do Transporte de Produtos Perigosos, e dá outras providências. Diário Oficial da União; Brasília; 2016, available at: https://anttlegis.datalegis.inf.br/action/UrIPublicasAction.php?acao=abrirAtoPublico\&num_ato=0000 5232\&sgl_tipo=RES\&sgl_orgao=DG/ANTT/MTPA\&vir_ano=2016\&seq_ato=000 (accessed 5 July 2021).

Brasil (1981), Lei n 6.938, de 31 de Agosto de 1981. Dispõe sobre a Política Nacional do Meio Ambiente, seus fins e mecanismos de formulação e aplicação, e dá outras providências. Diário Oficial República Federativa do Brasil, Brasília.

Brasil (1986), Resolução CONAMA n 18, de 6 de maio de 1986. Dispõe sobre a criação do Programa de Controle de Poluição do Ar por veículos Automotores - PROCONVE. Diário Oficial República Federativa do Brasil, Brasília.

Brasil. Ministério do Meio Ambiente. (2017), PROCONVE, available at: http://www.mma.gov.br/estruturas/163/_arquivos/proconve_163.pdf (accessed 1 April 2017).

Brunekreef, B., Annesi-Maesano, I., Ayres, J.G. et al. (2012), "Ten principles for clean air", The European Respiratory Journal, Vol. 39, No. 3, pp. 525-28.

Calderon-Garcidueñas. E., Leray, E., Reis, J. et al. (2016), “Air pollution, a rising environmental risk factor for cognition, neuroinflammation and neurodegeneration: the clinical impact on children and beyond", Revue Neurologique, Vol. 172, No. 1, pp. 69-80. https://doi.org/10.1016/j.neurol.2015.10.008. PMID: 26718591.

Castro, N. (2013), "Measurement of externalities of Brazilian cargo transport", Journal of Transport Literature, Vol. 7, No. 1, pp. 163-81.

Catela, E.Y.S. and Seabra, F. (2017), "Aglomerações produtivas e escolha de modal de transporte: um estudo de caso do setor industrial de São Paulo e Manaus", Revista Nova Econonomia, Vol. 27, No. 2, pp. 295-321. https://doi.org/10.1590/0103-6351/2785.

Cavico, F.J. and Mujtaba, B.G. (2016), Volkswagen emissions scandal: a global case study of legal, ethical, and practical consequences and recommendations for sustainable management", Global Journal of Research in Business \& Management, Vol. 4, No. 2, pp. 303-11.

Cepeda, M., Schoufour, J., Freak-Poli, R. et al. (2017), Levels of ambient air pollution according to mode of transport: a systematic review", Lancet Public Health, Vol 2, no, 1, available at: https://www.researchgate.net/publication/311651813_Levels_of_ambient_air_pollution_accor ding_to_mode_of_transport_a_systematic_review (accessed 6 April 2020).

Chiquetto, J.B. (2019), "Urban mobility and air pollution- synergies and co-benefits", available at: http://www.iea.usp.br/pesquisa/projetos-institucionais/usp-cidades-globais/artigosdigitais/mobilidade-urbana-e-poluicao-do-ar-sinergias-e-cobeneficios (accessed 6 April 2020).

Colavite, A.S. and Konishi, F. (2015). "The transport matrix in Brazil: a comparative analysis for competitiveness", available at: https://www.aedb.br/seget/arquivos/artigos15/802267.pdf (accessed 23 June 2021).

Coleti, J.C. and Oliveira, A.L.R. (2019), "A Intermodalidade no Transporte de Etanol Brasileiro: aplicação de um modelo de equilíbrio parcial", Revista de Economia e Sociologia Rural, Vol. 57, No. 1, pp. 127-44. http://dx.doi.org/10.1590/1234-56781806-94790570108.

Correa, S. and Arbilla, G. (2006), "Aromatic hydrocarbons emissions in diesel and biodiesel exhaust", Atmospheric Environment, Vol. 40, No. 35

Degobert, P. (1995), Automobiles and pollution, SAE Society of Automotive Engineers, Warrendale. 
Empresa de Pesquisa Energética - EPE (2015), “Brazilian energy balance 2015 year 2014”, EPE, Rio de Janeiro.

Frey, H.C. (2018), "Trends in onroad transportation energy and emissions", Journal of the Air \& Waste Management Association, Vol. 68, No. 6, pp. 514-63. http://dx.doi.org/10.1080/10962247.2018.1454357.

Galbieri, R., Brito, T.L.F., Mouette, D. et al. (2017), GHG mitigation due to the introduction of natural gas and ee measures in cargo transportation in Brazil", in International Gas Union Research Gas Conference 2017, Rio de Janeiro, pp. 1-11, avaliable at: https://www.researchgate.net/profile/Thiago-Brito-

3/publication/318404736_GHG_Mitigation_due_to_the_Introduction_of_Natural_Gas_and_Ene rgy_Efficiency_Measures_in_Cargo_Transportation_in_Brazil/links/5967b249a6fdcc18ea662c5 e/GHG-Mitigation-due-to-the-Introduction-of-Natural-Gas-and-Energy-Efficiency-Measures-inCargo-Transportation-in-Brazil.pdf (accessed 24 June 2021).

Galvao, O. (1996), "Transport development and regional integration in Brazil: a historical perspective", Planning and Public Policies, Vol. 1, No. 13, pp. 1-32.

Gouveia, N., Freitas, C.U., Martins, L.C. et al. (2006), Hospitalizações por causas respiratórias e cardiovasculares associadas à contaminação atmosférica no Município de São Paulo, Brasil. Cadernos de Saúde Pública, Vol. 22, No. 12, pp. 2669-2677. https://doi.org/10.1590/S0102$311 X 2006001200016$.

Hao, Y., Peng, H., Temulun, T. et al. (2018), "How harmful is air pollution to economic development? New evidence from PM2. 5 concentrations of Chinese cities", Journal of Cleaner Production, Vol. 172, pp. 743-57.

Institute of Interamerican Affairs (1954), Brazilian technical studies, Joint Brazil- U.S. Economic Development Commission, Washington, DC.

Instituto Brasileiro de Geografia e Estatistica - IBGE (2014), "Transport logistics", avaliable at: <https://geoftp.ibge.gov.br/organizacao_do_territorio/redes_e_fluxos_geograficos/logistica_d os_transportes/Nota_tecnica_da_Logistica_dos_Transportes_no_Brasil_2014_20191031.pdf (access 24 June 2021).

Kim, D., Chen, Z., Zhou, L.F. et al. (2018), "Air pollutants and early origins of respiratory diseases", Chronic Dis Trans/ Med., Vol. 4, No. 2, pp. 75-94. http://dx.doi.org/10.1016/j.cdtm.2018.03.003.

Knothe, G., Van, G.J. and Krahl, J. (2005), The Usahe Biodiesel Handbook, Taylor \& Francis, Champaign.

Martins, P.P.P., Boaventura, J.M.G., Fischmann, A.A. et al. (2012), “Scenarios for the Brazilian road freight transport industry", Foresight, Vol.14, No. 3, pp. 20724. https://doi.org/10.1108/14636681211239755.

Minas Gerais. Governo. (2018), Meet Minas, 2018. Brazilian Institute OF Infrastructure.

Minayo, M.C.S. (1993), The Challenge of Knowledge: Qualitative Research in Health, Hucitec Publishing House, São Paulo.

Neeft, J., Makkee, M. and Moulijn, J. (1996), "Catalysts for the oxidation of fuligem de gases de escape de diesel. I. Um estudo exploratório", Catálise B aplicada: Ambiental, Vol. 8, No. 1, pp. 57-78. https://doi.org/10.1016/0926-3373(95)00057-7.

Nicolaides, D., Cebon, D. and Miles, J. (2017), "Prospects for electrification of freight transportation", IEEE Systems Journal, Vol. 12, No. 2, pp. 1838-49. http://dx.doi.org/10.1109/JSYST.2017.2691408.

Petrobras (2017), Diesel oil, available at: http://www.anp.gov.br/wwwanp/petroleo-derivados/155combustiveis/1857-oleo-diesel (accessed 1 April 2017).

Plano Nacional de Logística - PNL (2016), Transporte inter-regional de carga no Brasil - Panorama 2015. available at: https://www.epl.gov.br/transporte-inter-regional-de-carga-no-brasilpanorama-2015 (access 6 April 2020).

Rüstemoglu, H. and Andrés, R.A. (2016), “Determinants of CO2 emissions in Brazil and Russia between 1992 and 2011: a decomposition analysis", Environmental Science \& Policy, Vol. 58, pp. 95-106.

Santana, E., Borges, K.C., Ferreira, A. L. et al. (2012). Air Quality Standards Compared Experience Brazil, USA and European Union. Institute of Energy and Environment. 
Santos Junior, D.A.M. (2015) Emissões veiculares em São Paulo: quantificação de fontes com modelos receptores e caracterização do material carbonáceo, Dissertação de Mestrado, Instituto de Física, Universidade de São Paulo, São Paulo, SP, available at https://www.teses.usp.br/teses/disponiveis/43/43134/tde-17072015135624/publico/SantosJunior.pdf (accessed 5 July 2021).

Scheepers, P.T.J. and Bos, R.P. (1992), "International archives of occupational and environmental health", Environmental Sciences, Vol. 1, No. 8.

Sindicato das Empresas de Transporte de Cargas do Triângulo Mineiro - SETTRIM (2017), Interview Open, SETTRIM, Uberlândia.

Southworth, J., Marsik, M., Qiu, Y. et al. (2011), “Roads as drivers of change: trajectories through the tri-national frontier in MAP, the Southwestern Amazon", Remote Sensing. Vol. 3, No. 5, pp. 104766. https://doi.org/10.3390/rs3051047.

Stern, D.I. and Van Dijk, J. (2017), "Economic growth and global particulate pollution concentrations", Climatic Change, Vol. 142, No. 3-4, pp. 391-406.

Talebian, H., Herrera, O.E., Tran, M. et al. (2018), "Electrification of road freight transport: policy implications in British Columbia", Energy Policy, Vol. 115, pp. 109-18.

United States Environmental Protection Agency (2017), "AP-42: Compilation of air pollutant emission factors", available at: http://www.epa.gov/oms/ap42.htm (accessed 10 June 2017).

Vieira, N.D.B., Nogueira, L.A.H. and Haddad, J. (2018), "An assessment of CO2 emissions avoided by energy-efficiency programs: a general methodology and a case study in Brazil", Energy, Vol. 142, pp. 702-15.

Weiss, M., Dekker, P., Moro, A. et al. (2015), "On the electrification of road transportation - A review of the environmental, economic, and social performance of electric two-wheelers", Transportation Research Part D: Transport and Environment, Vol. 41, pp. 348-366.

World Health Organization - WHO. (2000), Air Quality Guidelines for Europe, WHO, Copenhagen, WHO regional publications. European series, No. 91.

Yang, B.Y., Guo, Y., Markevich, I. et al. (2019), "Association of long-term exposure to ambient air pollutants with risk factors for cardiovascular disease in China", JAMA Network Open, Vol. 2, No. 3, pp. e190318.

Zhang, Q., Jiang, X., Tong, D. et al. (2017), “Transboundary health impacts of transported global air pollution and international trade", Nature, Vol. 543, No. 7647, pp. 705-9.

Author contributions: All the authors contributed equally to this paper. 